\title{
Effects of Tonicity on the Pacemaker Activity of Guinea-pig Sino-atrial Node
}

\author{
Mitsuyoshi OHBA \\ Department of Physiology, School of Medicine, \\ Fukuoka University, Fukuoka, 814-01 Japan
}

\begin{abstract}
Spontaneously beating sino-atrial node (S-A node) of guineapig was superfused with solutions of various osmolarities. The changes in the rate of spontaneous beating and in action potentials were measured. In the solution of normal tonicity, the rate of spontaneous beating was $214 \pm 6$ beats/min (mean \pm S.E.) and the maximum rate of rise was $9.7 \pm 2.5 \mathrm{~V} / \mathrm{s}$. When extracellular $\mathrm{Na}^{+}$was reduced by $33 \%$, isotonically replaced with sucrose, the heart rate was reduced to $177 \pm 8$ beats/min and the maximum rate of rise was reduced to $7.6 \pm 1.2 \mathrm{~V} / \mathrm{s}$. Decreasing the osmolarity by $30 \%$ increased the heart rate by $6 \%$ and increasing the osmolarity to 130,150 , and $170 \%$ decreased the heart rate to 94,89 , and $73 \%$, respectively, in low $\mathrm{Na}^{+}$medium. The tonicity dependence of the heart rate was not affected by TTX, atropine, phentolamine, or propranolol. When the tonicity was either increased twice or decreased half, the spontaneous beating stopped. Adding either $\mathrm{K}^{+}$or $\mathrm{Rb}^{+}$of $6 \mathrm{~mm}$ to the solution which was two times as hypertonic as the normal, could activate the beating again. Substances inhibiting the potassium conductance such as tetraethylammonium (TEA), 4-aminopyridine (4-AP), and cesium chloride $(\mathrm{CsCl})$ could also reactivate the spontaneity. Although lowering extracellular $\mathrm{Ca}^{2+}$ concentration could reactivate the spontaneity in the hypertonic medium, increasing $\mathrm{Mg}^{2+}$ inhibited the reactivation. The contribution of $\mathrm{K}^{+}$current in the effects of changing osmolarity on the spontaneous beating is discussed.
\end{abstract}

Key words: sino-atrial node, tonicity, pacemaker activity, $\mathrm{K}^{+}$channel blocker.

Change in osmolarity of the perfusate can affect both electrical and mechanical activities of heart muscle cells through water movement into or out of cells. There are very few studies on pacemaker activity (VASSALLE, 1965; Wildenthal et al., 1969; AtKins et al., 1973; RoBerts and Hughes, 1977). In sheep Purkinje fibres, VASSALLE (1965) showed that hypertonicity slowed the spontaneous rate and the

Received for publication July 2, 1986 
opposite result occurred with hypotonic medium. The author suggested that the cell shrinkage and a resultant increase in the intracellular $\mathrm{K}^{+}$concentration may be the cause. In anesthetized, open-chest dogs, WildentHal et al. (1969) showed that hypertonic infusions caused a tachycardia which was preceded by a transient bradycardia. And the bradycardia component of the heart rate response was eliminated by pretreatment with reserpine, propranolol, and vagotomy. ATKINS et al. (1973) showed that intravenous infusions of mannitol to anesthetized and conscious dogs, which raised the serum osmolarity by $15-25 \mathrm{mOsm} / \mathrm{kgH}_{2} \mathrm{O}$, were accompanied by elevation in heart rate. ROBERTS and HuGHES (1977) aimed to clarify the above disparity and showed that the chronotropic response of spontaneously-active isolated atria from rabbits to hyperosmolar solutions is positive.

In spite of these observations, underlying mechanisms for the chronotropic response of various species to the change in tonicity were still ambiguous.

In the present study, S-A node of guinea-pig was used as an isolated preparation and the chronotropic response as well as intracellular potentials were examined over a wide range of osmolarity $(150-600 \mathrm{mOsm} / l)$. The results were discussed on the basis of pacemaker currents which were most widely and newly examined in the rabbit S-A node.

\section{METHODS}

Guinea-pigs of either sex weighing 300-400 g were stunned and bled. The heart was excised quickly and placed in an oxygenated Tyrode solution at $35^{\circ} \mathrm{C}$. The S-A node lying in the lateral wall of the superior vena cava at its junction with the right atrial appendage and the posterior atrial wall (ANDERSON, 1972) was dissected out. Small S-A node specimens were prepared (approximately $0.5 \times 0.5 \mathrm{~mm}$ ) by cutting and then pinned down to the bath floor.

A conventional microelectrode (resistance of around $20 \mathrm{M} \Omega$ ) filled with $3 \mathrm{M}$ $\mathrm{KCl}$ solution and a standard electrophysiological set-up were used for recording extracellular and intracellular membrane potentials.

The rate of discharges of the primary pacemaker cells was measured by recording the extracellular potential changes with a pair of thin $\mathrm{Ag}-\mathrm{AgCl}$ electrodes placed on the pacemaker region. In case of disappearance of electrical discharges during perfusion with either 2 or $0.5 \mathrm{~T}$ solution (see below), the position of the electrodes was changed to explore the electrical sign. Thus the arrest of spontaneous activity in hypertonic (twice that of normal) or in hypotonic (half of normal) solution can be differentiated from the conduction block in the nodal region.

The modified Tyrode solution had the following composition (mM): $\mathrm{NaCl} 125$; $\mathrm{KCl} 3 ; \mathrm{CaCl}_{2}$ 1.8; $\mathrm{MgCl}_{2}$ 1.8; $\mathrm{NaHCO}_{3} 20$; glucose 11.1. It was saturated with a mixture of $95 \% \mathrm{O}_{2}$ and $5 \% \mathrm{CO}_{2}$. The $\mathrm{pH}$ was 7.3 and the bath, containing $0.2 \mathrm{ml}$ of solution, was perfused at a rate of $3 \mathrm{ml} / \mathrm{min}$.

The osmolarity of the solutions used in the experiment was examined occasionally by an osmometer ( $3 \mathrm{~W}$, Advance). The modified Tyrode solution had 
the osmolarity, $300 \mathrm{mOsm} / l$. To prepare solutions of any tonicity without change in $\mathrm{Na}^{+}$, the $\mathrm{NaCl}$ concentration in the control solution $(1 \mathrm{~T})$ was lowered to $77 \mathrm{mM}$ (45 $\mathrm{mm}$ in Fig. 3B) and the osmolarity was maintained by adding sucrose.

Hypotonic solutions $(0.5$ and $0.7 \mathrm{~T})$ were made by omitting sucrose and hypertonic solutions $(1.3,1.5,1.8$, and $2.0 \mathrm{~T})$ were made by addition of sucrose.

Stock solutions of $1 \mathrm{~m} \mathrm{CsCl}, 1 \mathrm{~m} \mathrm{TEAC1}, 0.25 \mathrm{~m} 4-\mathrm{AP}$, and $1 \mathrm{M} \mathrm{RbCl}$ were prepared and added to solutions before each experiment.

The following drugs were used in the present study: phentolamine mesylate (CIBA), propranolol hydrochloride (Sumitomo, Japan), atropine sulfate (Sigma Chemical Co.), and tetrodotoxin (TTX) (Sankyo).

\section{RESULTS}

Effects of tonicity on the spontaneous rate

Figure 1 shows the extracellular potentials from the primary pacemaking area recorded with a bipolar surface electrode. In normal Tyrode solutions $(300 \mathrm{mOsm} / l)$, the rate of spontaneous beating was $214 \pm 6$ beats/min (mean \pm S.E., $n=39$ ). When the extracellular $\mathrm{Na}$ concentration ([Na $]_{\mathrm{o}}$ ) was lowered to $77 \mathrm{~mm}$ isotonically by addition of sucrose $(1.0 \mathrm{~T})$, the rate was reduced to $177 \pm 8$ beats $/ \mathrm{min}$
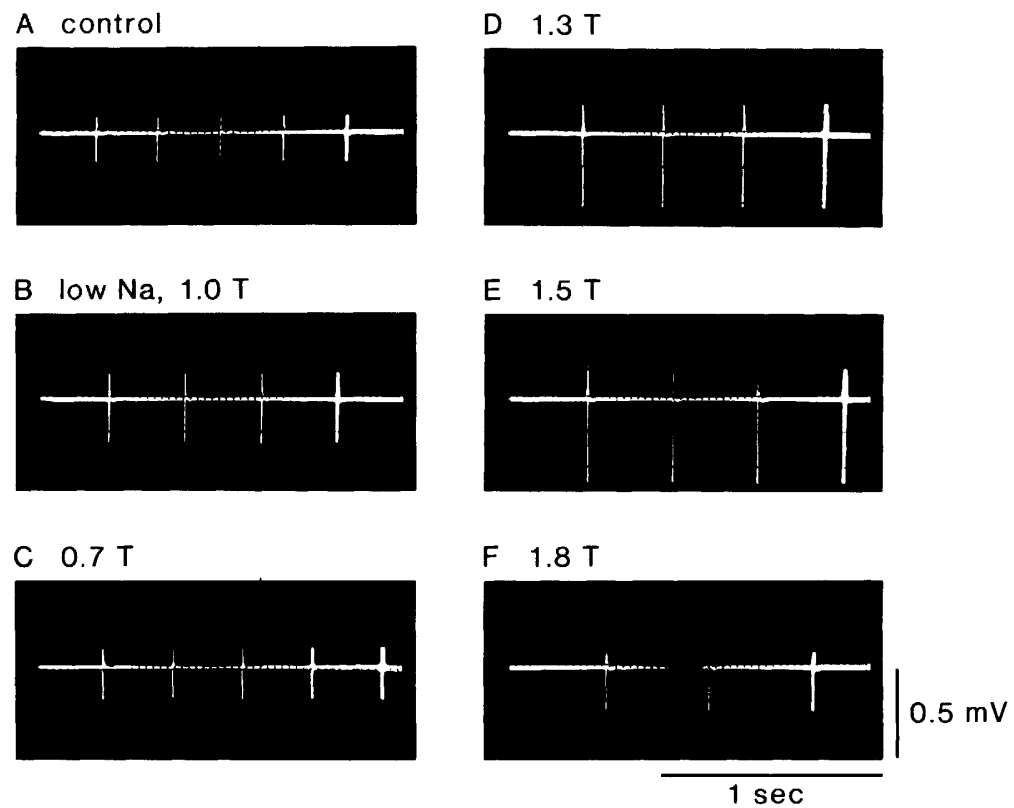

Fig. 1. Changes in extracellular potentials induced by various tonicities. A was recorded in the modified Tyrode solution. B was in $77 \mathrm{~mm} \mathrm{NaCl}$ and $88 \mathrm{~mm}$ sucrosecontaining solution. Tonicities were varied either by omitting sucrose from or by adding sucrose to the solution used in B (C-F). 
Table 1. Effects of drugs on the rate of spontaneous beating.

\begin{tabular}{lcl}
\hline & Rate of beating (beats/min) \\
\hline Control & $177 \pm 8$ \\
TTX $\left(2 \times 10^{-6} \mathrm{~g} / \mathrm{ml}\right)$ & $164 \pm 8^{*}$ & $(8)$ \\
Control & $179 \pm 6$ & \\
Atropine $\left(10^{-7} \mathrm{M}\right)$ & $180 \pm 6 \quad(11)$ \\
Control & $181 \pm 8$ \\
Propranolol $\left(3.4 \times 10^{-6} \mathrm{M}\right)$ & $182 \pm 11 \quad(11)$ \\
Control & $175 \pm 4 \quad$ \\
Phentolamine $\left(10^{-6} \mathrm{M}\right)$ & $173 \pm 3 \quad(9)$ \\
\hline
\end{tabular}

Mean \pm S.E. The rate was measured from the extracellular potential recorded in the $77 \mathrm{~mm} \mathrm{NaCl}$ isotonic solution. The number of experiments is given in parentheses. $p$ values are compared to each control and determined by paired $t$-test. ${ }^{*} p<0.05$.

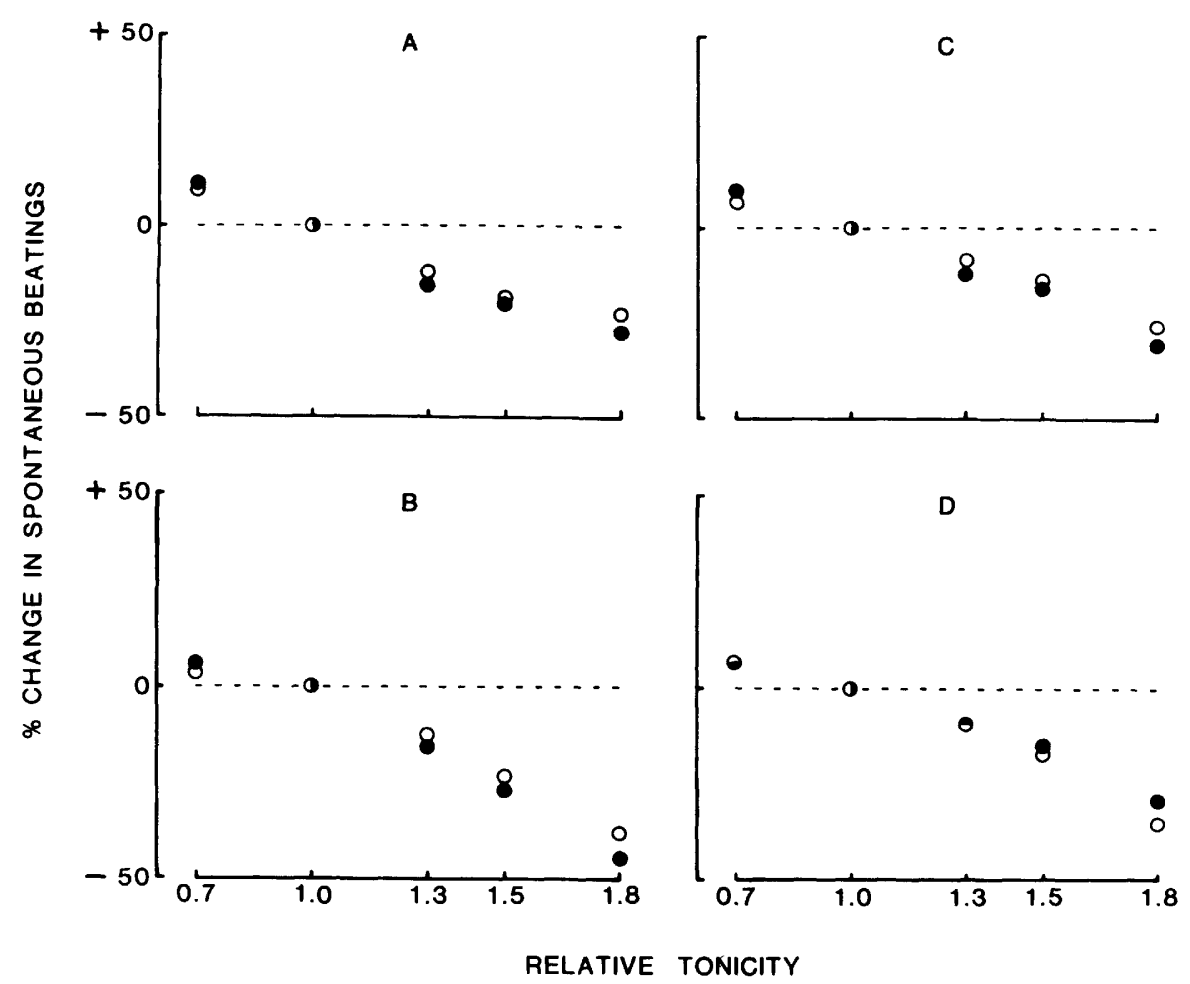

Fig. 2. Relation between tonicity and $\%$ change in rhythmic firing rate. Open circles were recorded in drug-free solutions. Closed circles were recorded in each solution containing $2 \times 10^{-6} \mathrm{~g} / \mathrm{ml}$ TTX (A), $10^{-7} \mathrm{M}$ atropine (B), $3.4 \times 10^{-6} \mathrm{M}$ propranolol (C), and $10^{-6} \mathrm{M}$ phentolamine (D). The rate at each $1.0 \mathrm{~T}$ solution was taken as $100 \%$. Each point was an average of 3-10 samples. 
$(n=39)$. Normally the spontaneous beating was arrested when $[\mathrm{Na}]_{\mathrm{o}}$ was less than $30 \mathrm{~mm}$ (not shown). Lowering the osmolarity of bathing medium to $0.7 \mathrm{~T}$ $(210 \mathrm{mOsm} / l)$, the rate was increased to $193 \pm 4$ beats $/ \mathrm{min}(n=29)$. When the osmolarity was increased to $1.3 \mathrm{~T}(390 \mathrm{mOsm} / l), 1.5 \mathrm{~T}(450 \mathrm{mOsm} / l)$, and $1.8 \mathrm{~T}$ $(540 \mathrm{mOsm} / l)$, the rate was reduced to $166 \pm 5(n=33), 158 \pm 6(n=32)$, and $129 \pm 16$ beats/min $(n=18)$, respectively.

Table 1 shows the effects of $2 \times 10^{-6} \mathrm{~g} / \mathrm{ml} \mathrm{TTX}, 10^{-7} \mathrm{M}$ atropine, $3.4 \times 10^{-6} \mathrm{M}$ propranolol, and $10^{-6} \mathrm{M}$ phentolamine on the rate of rhythmic firing in low $[\mathrm{Na}]_{\mathrm{o}}$, $1.0 \mathrm{~T}$ solution. Only TTX induced somewhat significant changes. The result suggests a contribution of TTX-sensitive Na current to the spontaneous activity of guineapig S-A node.

To explore any contribution of neural effects (ANDERSON, 1972) on the chronotropic response, the tonicity dependence was examined under these drugs; none affected the tonicity dependence of the rate of spontaneous beating (Fig. 2).

\section{Effects of tonicity on membrane potentials}

S-A node cells of guinea-pig used in the present study generated spontaneous

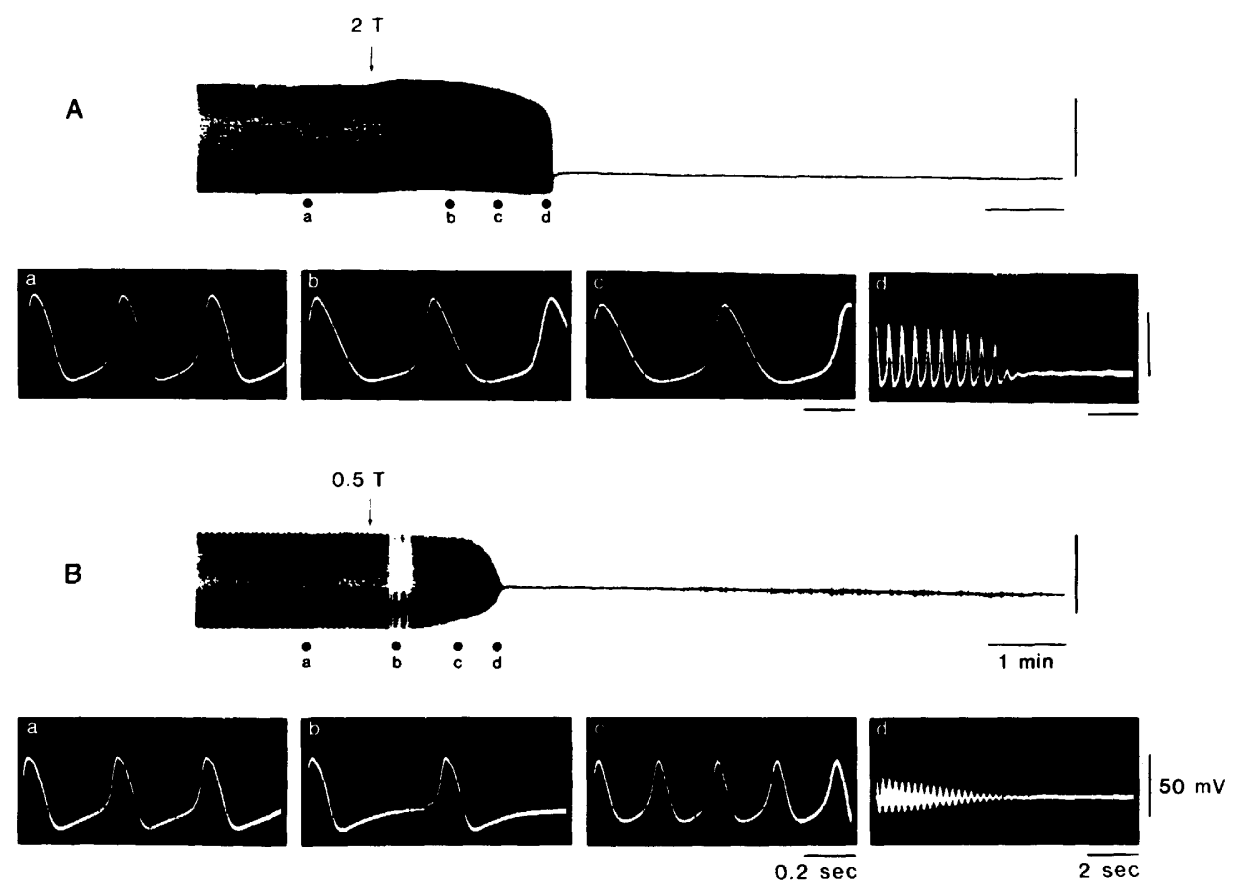

Fig. 3. Effects of tonicity on intracellular potentials. Effect of $2 \mathrm{~T}(\mathrm{~A})$ or $0.5 \mathrm{~T}$ (B). Upper trace was a record on a chart at slower speed. Lower panels were photographed. The action potentials were recorded at the times indicated by the dots and letters below the trace. Note slower speed in d. Different tissues were used in $\mathrm{A}$ and $\mathrm{R}$. 
action potentials; the amplitude of the maximum upstroke velocity was $9.7 \pm 2.5 \mathrm{~V} / \mathrm{s}$ $(n=18)$ and the maximum diastolic potential was $-61.7 \pm 3.3 \mathrm{mV}(n=18)$. The maximum upstroke velocity of the action potential was somewhat larger and the maximum diastolic potential was less positive than values noted by OPтHOF et al. (1985).

Figure $3 \mathrm{~A}$ shows the effects of $2 \mathrm{~T}$ solution on spontaneous action potentials. The maximum rate of rise became smaller; the diastolic depolarization rate was gradually suppressed; and the duration of action potential was prolonged. Thus the cycle length was lengthened. At the final stage of the response to $2 \mathrm{~T}$ solution, the amplitude of action potentials became smaller and the spontaneous activity ceased at around $-50 \mathrm{mV}$. The spontaneous action potentials never resumed as long as SA node was immersed in $2 \mathrm{~T}$ solution.

When the preparation was superfused with the $0.5 \mathrm{~T}$ solution, although the spontaneous activity ceased at around $-40 \mathrm{mV}$, somewhat different changes in action potential configuration were observed. The diastolic depolarization rate was
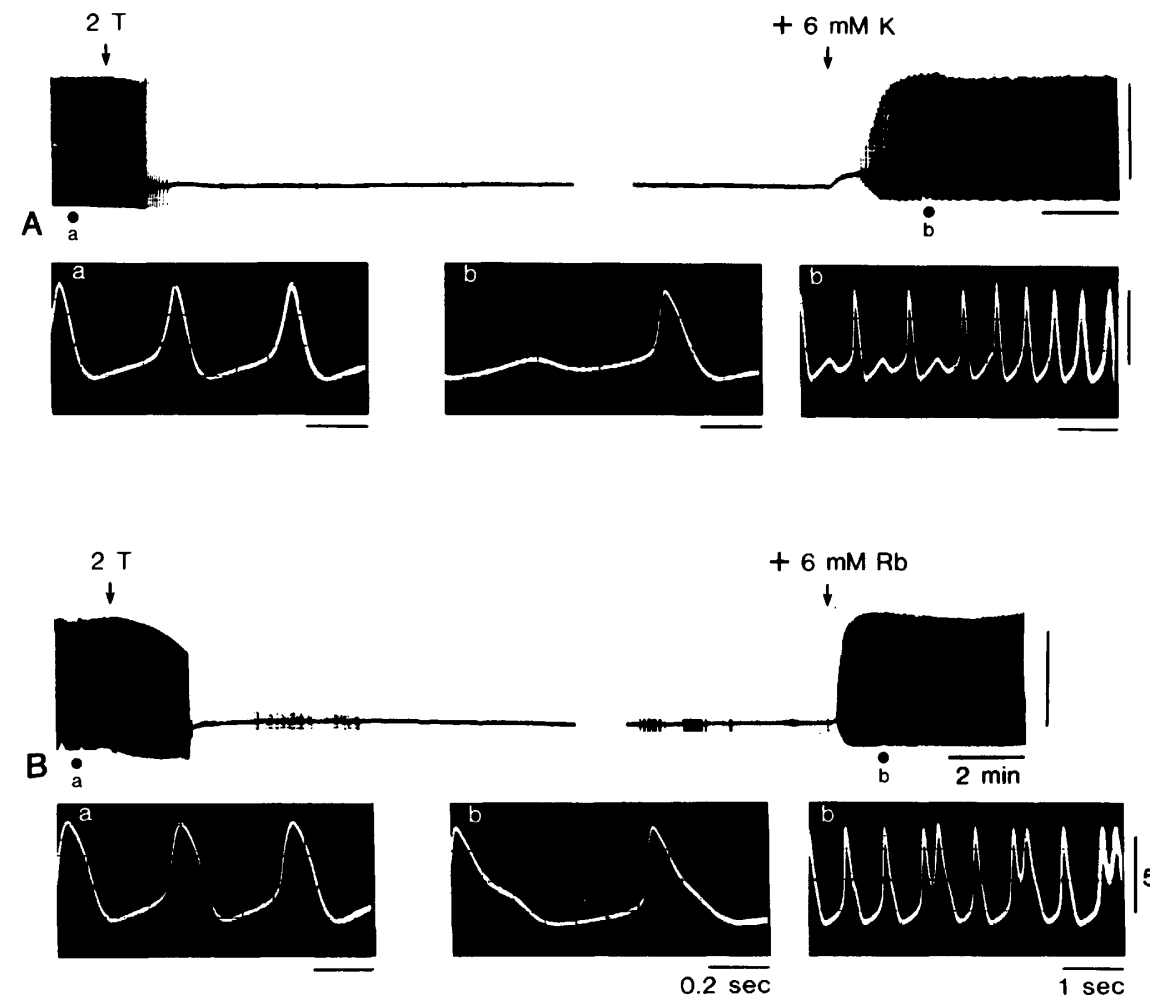

$$
+6 \mathrm{mM} \mathrm{Rb}
$$

$\downarrow$
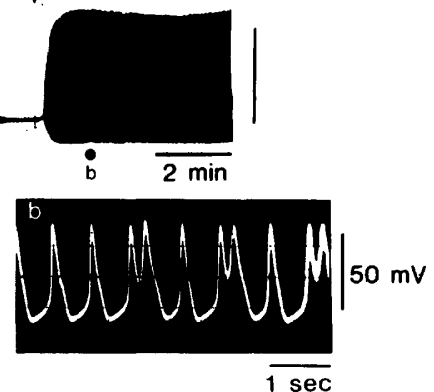

Fig. 4. Effects of extra $\mathrm{K}^{+}$and $\mathrm{Rb}^{+}$on the arrested membrane potential. Six mM KCl (A) or $6 \mathrm{mM} \mathrm{RbCl} \mathrm{(B)} \mathrm{was} \mathrm{added} \mathrm{after} 20 \mathrm{~min}$ perfusion of $2 \mathrm{~T}$ solution (dots and small letters as in Fig. 3). Middle and right panels were recorded at the same time but the right panel was displayed at slow speed. 
greatly but transiently suppressed and thereafter the rate was accelerated. The duration and the maximum rate of rise of action potentials were not much affected. Thus the cycle length was shortened. The maximum diastolic potential was gradually depolarized and action potentials altered to the oscillatory potential. As in $2 \mathrm{~T}$ solution, the spontaneous activity did not recover during the perfusion of $0.5 \mathrm{~T}$ solution.

\section{$K^{+}$and $R b^{+}$on the arrested $S-A$ node}

The expected change in hypertonic solutions is an increase in intracellular potassium activity (FozZARD and LEE, 1976). Thus increased $\mathrm{K}^{+}$efflux may affect the spontaneous activity. To reduce this increased $\mathrm{K}^{+}$efflux, reducing the driving force for $\mathrm{K}^{+}$was tried.

Increasing the extracellular $\mathrm{K}^{+}$concentration by $6 \mathrm{~mm}$ after perfusion of $2 \mathrm{~T}$ solution for $20 \mathrm{~min}$ induced depolarization of about $7 \mathrm{mV}$ (Fig. 4A). Then the spontaneous activity occurring initially was small and irregular, but later it attained a regular beating. The action potential was almost the same as that before perfusion of $2 \mathrm{~T}$ solution except the duration was still prolonged.

$\mathrm{Rb}^{+}$is known to substitute for $\mathrm{K}^{+}$in the activation of $\mathrm{Na}^{+}-\mathrm{K}^{+}$pump in rabbit atrioventricular and S-A nodes (KURACHI et al., 1981; Gото et al., 1982). When $6 \mathrm{mM} \mathrm{Rb}^{+}$was added to $2 \mathrm{~T}$ solution $20 \mathrm{~min}$ after the perfusion, with only a small depolarization, the spontaneous action potential was reactivated (Fig. 4B). There appeared a notch in the falling phase of action potentials and sometimes induced the regenerative discharge. The rate of diastolic depolarization was not recovered completely in these resumed action potentials by $\mathrm{K}^{+}$and $\mathrm{Rb}^{+}$; thus the spontaneous rhythm was slow compared to that in $1 \mathrm{~T}$ solution.

\section{Effects of $\mathrm{K}^{+}$channel blockers on the arrested $S$ - $A$ node}

Another way to reduce the $\mathrm{K}^{+}$efflux is to use agents which will block various $\mathrm{K}^{+}$currents underlying the spontaneous action potential (NOBLE, 1984).

TEA is known to suppress the early outward $\mathrm{K}^{+}$current (KENYON and GiBBONS, 1979a) but does not affect the pacemaker current $\left(\Delta I_{\mathrm{p}}\right)$ of rabbit $S$-A node cell (MAYLIE and MORAD, 1984). On addition of $6 \mathrm{~mm}$ TEA at $16 \mathrm{~min}$ after perfusion of $2 \mathrm{~T}$ solution, the small oscillatory potential was firstly induced without significant membrane polarization. Thereafter regular but widened action potentials with the slower diastolic depolarization were attained (Fig. 5A).

The transient outward $\mathrm{K}^{+}$current is blocked by 4-AP at its low dose; however, the high dose of 4-AP used in this study will reduce the inwardly rectifying background $\mathrm{K}^{+}$current $\left(I_{\mathrm{K} 1}\right)$ (KENYON and GIBBONS, 1979b; VAN BOGAERT and SNYDERS, 1982; GILES and VAN GINNEKEN, 1985). In rabbit S-A nodes the $I_{\mathrm{K} 1}$ is less involved (Noma et al., 1984). Six mM 4-AP applied after 16 min of perfusion in $2 \mathrm{~T}$ solution could resume the spontaneous action potential. The duration of action potentials were prolonged and the diastolic depolarization was much slowed. Regenerative discharges at the plateau level of the action potential occurred more 

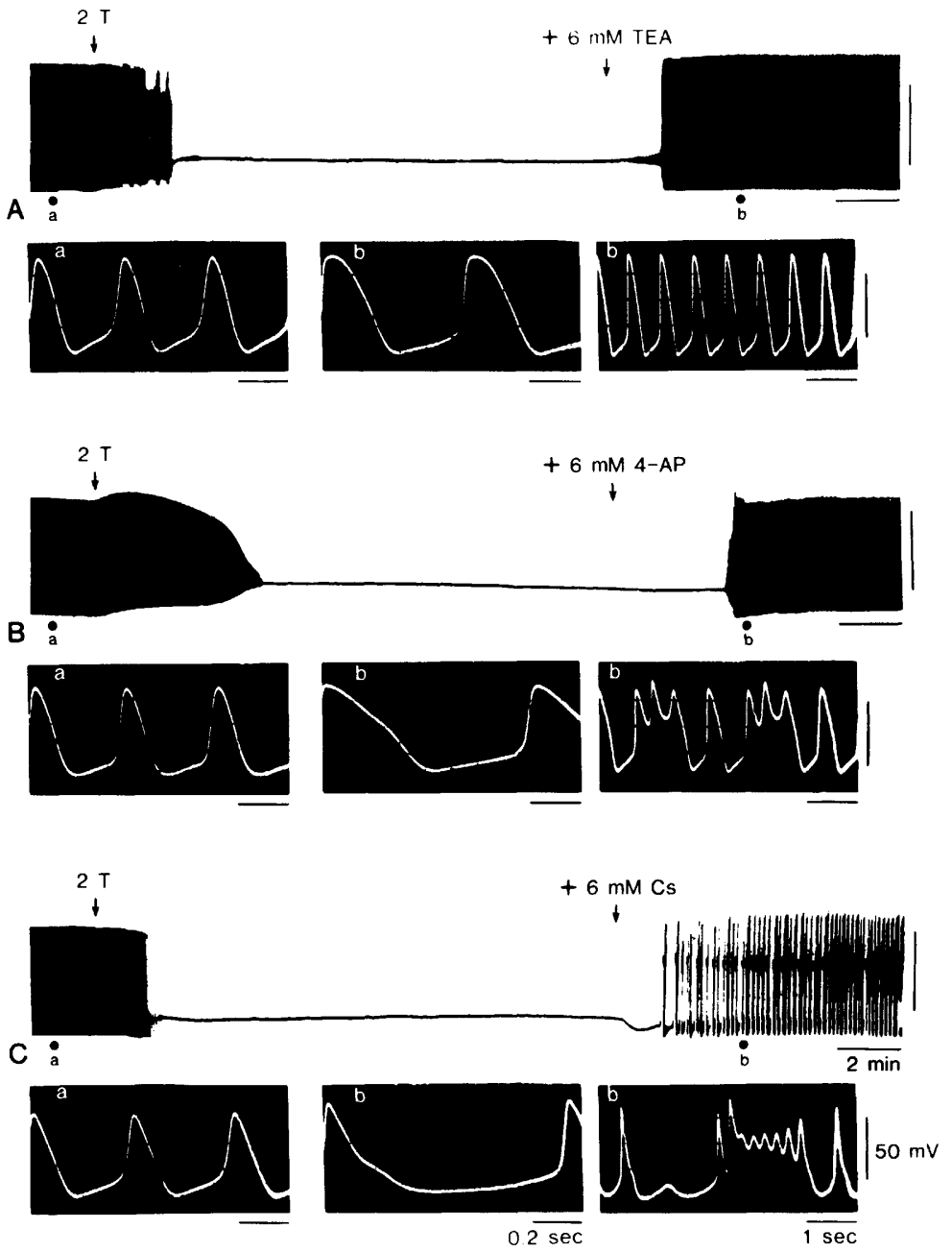

Fig. 5. Effects of $\mathrm{K}^{+}$channel blockers on the arrested membrane potential. Six $\mathrm{mm}$ TEA (A), $6 \mathrm{~mm}$ 4-AP (B), or $6 \mathrm{~mm} \mathrm{CsCl} \mathrm{(C)} \mathrm{was} \mathrm{added} \mathrm{in} \mathrm{the} \mathrm{perfusate} \mathrm{at} \mathrm{about}$ 16 min after perfusion of $2 \mathrm{~T}$ solution (dots and small letters as in Fig. 3).

frequently than in TEA (Fig. 5B).

$\mathrm{Cs}^{+}$is a specific inhibitor of the pacemaker current $\left(I_{\mathrm{f}}, I_{\mathrm{h}}, \Delta I_{\mathrm{p}}\right)$ at the dose used in the present study (DifRAnCeSCO, 1981; Noma et al., 1983; MaYlie and Morad, 1984). When $6 \mathrm{mM} \mathrm{Cs}^{+}$was applied in the perfusate of $2 \mathrm{~T}$, the membrane potential was hyperpolarized transiently and on the recovery to the control potential level, the spontaneous action potential was reactivated. The diastolic depolarization was kept slow and the small oscillatory potential sometimes failed to initiate regenerative action potentials (Fig. 5C). 


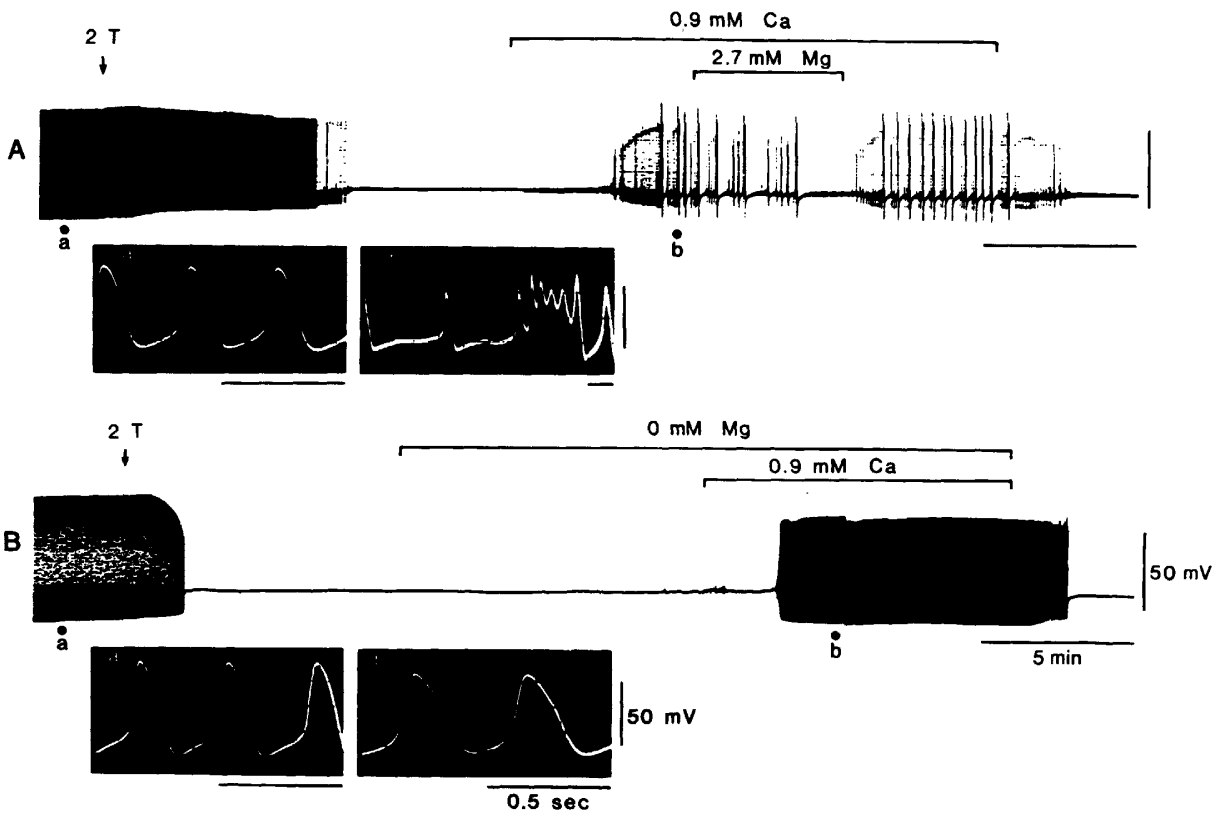

Fig. 6. Effects of divalent ions on the arrested membrane potential. In $\mathrm{A}, \mathrm{Ca}^{2+}$ was reduced to half of the normal concentration during which $\mathrm{Mg}^{2+}$ was increased by $50 \%$. In $\mathrm{B}$, firstly $\mathrm{Mg}^{2+}$ was omitted from the perfusate and later on $\mathrm{Ca}^{2+}$ was reduced to half (dots and small letters are as in Fig. 3).

Finally, TEA failed to resume the spontaneous action potentials in two of four experiments and 4-AP failed in one of three experiments; however, $\mathrm{Cs}^{+}$never failed to resume the spontaneous action potentials in five tests and always induced the transient hyperpolarization of about $4-8 \mathrm{mV}$ after application of the agent.

\section{$\mathrm{Ca}^{2+}$ on the arrested $\mathrm{S}-\mathrm{A}$ node}

The results obtained so far suggest the large contribution of $\mathrm{K}^{+}$currents to the slowing of rhythmic firing by the hypertonic solution and to the arrest by $2 \mathrm{~T}$ solution. MAYLIE and MORAD (1984) suggested that $\mathrm{Ca}^{2+}$ alters the rate of pacing through activation of a $\mathrm{K}^{+}$conductance. Here the possibility was examined.

When the extracellular $\mathrm{Ca}^{2+}$ concentration $\left([\mathrm{Ca}]_{0}\right)$ was halved during the perfusion of $2 \mathrm{~T}$ solution, regenerative action potentials irregularly appeared following small oscillatory potentials; however, increasing the extracellular $\mathbf{M g}^{2+}$ concentration arrested the spontaneity again (Fig. 6A). The result suggests that the threshold membrane potential may be affected by $2 \mathrm{~T}$ solution. In this tissue $\mathbf{M g}^{2+}$ slows the diastolic depolarization in the normal $1 \mathrm{~T}$ solution (not shown), the arrest may be induced by the direct action of $\mathrm{Mg}^{2+}$ on the action potentials. However, omitting the $\mathrm{Mg}^{2+}$ from the bathing solution of $2 \mathrm{~T}$ could not induce the 
spontaneous action potentials. Under the $\mathrm{Mg}^{2+}$-free condition, lowering $[\mathrm{Ca}]_{\mathrm{o}}$ still could resume the spontaneous action potentials although the duration was prolonged (Fig. 6B). Thus the possible role of the $\mathrm{Ca}^{2+}$ induced $\mathrm{K}^{+}$conductance change on the arrest of spontaneous beating by $2 \mathrm{~T}$ solution cannot be ruled out.

\section{DISCUSSION}

S-A node preparations from guinea-pig used in the present study had similar electrophysiological characteristics to the one reported by OpтHоF et al. (1985). They showed the maximum upstroke velocity of $6.2 \mathrm{~V} / \mathrm{s}$ and the maximum diastolic potential of $-57 \mathrm{mV}$. The spontaneous transmembrane action potentials were arrested when either $[\mathrm{Na}]_{\mathrm{o}}$ was reduced below $30 \mathrm{~mm}\left(29 \%\right.$ of control $\left.[\mathrm{Na}]_{\mathrm{o}}\right)$ or $[\mathrm{Ca}]_{\mathrm{o}}$ was reduced below $0.3 \mathrm{~mm}$ in the isotonic solution. These observations are in line with another study indicating that the slow inward current is responsible for the generation of the spontaneous action potentials and to some extent for the pacemaker depolarization in rabbit S-A node (IRISAWA and NomA, 1982).

Some authors have investigated the effects of tonicity on transmembrane potentials (HermsmeYer et al., 1972; AKIYAma and Fozzard, 1975; BAILeY, 1981; Ehara and Hasegawa, 1983) and on the intracellular $\mathrm{K}^{+}$activity (FozZARD and LEE, 1976); however, those are not on either A-V or S-A node. In the present study the S-A node of guinea-pig was used to explore the effects of tonicity on the electrical activity of pacemaker cells. Change in the tonicity will cause water movement into or out of cells and then alter the various intracellular ionic activities (LADO et al., 1984). These alterations possibly affect ionic currents (including such as those generated by ion pumps and ion exchange mechanisms) which may be responsible for the pacemaker activity. At present, however, only the role of $\mathrm{K}^{+}$as the underlying mechanism of the change in spontaneous rhythm was investigated.

The present study showed that hypotonicity increases the firing rate, and hypertonicity reduces it in the guinea-pig S-A node. When the osmolarity of bathing medium was increased twice or havled, the spontaneous beating was arrested. Since the spontaneous action potential was resumed by the protocol which may reduce the driving force for $\mathrm{K}^{+}$, the result supports the idea proposed by VASSALLE (1965) that an increase in intracellular $\mathrm{K}^{+}$concentration by cell shrinkage will increase $\mathrm{K}^{+}$efflux in Purkinje fibers.

$\mathrm{Rb}^{+}$was aimed in the present study to act as an activator of $\mathrm{Na}^{+}-\mathrm{K}^{+}$pump (KURACHI et al., 1981; Goto et al., 1982). Since a low affinity of the pump site ( $K_{\mathrm{m}}$ about $6 \mathrm{~mm}$ ) was shown in sheep Purkinje fibers (EISNER and LEDERER, 1980), $6 \mathrm{~mm}$ of $\mathrm{Rb}^{+}$was used in the present study. This is also the reason why relatively high but the same concentration of $\mathrm{K}^{+}$current blockers for the comparison of the effects were used. $\mathrm{Rb}^{+}$is also known to block the $I_{\mathrm{f}}$ (DIFRANCESCO, 1982); then the result in Fig. 4B may also be explained by the effect of $\mathrm{K}^{+}$channel blocker. However, such a high dose of chemicals will affect various $\mathrm{K}^{+}$channels known in heart muscle cells and will exert overlapped effects. In this sense, if any specific $\mathrm{K}^{+}$channel should be 
identified as causing the change in rhythm induced by tonicity, careful choice of the chemical concentration will be necessary.

In the rabbit S-A nodal cells, the turn-off of a $\mathrm{K}^{+}$conductance as the primary mechanism was not responsible for the generation of the pacemaker potential (MAYLIE et al., 1981). The density of inward rectifier $\mathrm{K}^{+}$channel was very small (Noma et al., 1984) and the pacemaker current $\left(I_{\mathrm{h}}, \Delta I_{\mathrm{p}}\right)$ plays a minor role in the generation of pacemaker depolarization (NomA et al., 1983; MAYLIE and MORAD, 1984). Although those are not known in the guinea-pig S-A node, the present study shows that the $\mathrm{K}^{+}$current may at least modify the underlying ionic currents for the pacemaker depolarization.

It remains to be determined whether the $\mathrm{K}^{+}$conductance change suggested in this report is modulated by $\mathrm{Ca}^{2+}$. MAYLIE and MoRAD (1984) suggested that $\mathrm{Ca}^{2+}$ alters the rate of pacing through activation of a $\mathrm{K}^{+}$conductance. When $\mathrm{S}-\mathrm{A}$ node was exposed to $0.5 \mathrm{~T}$ solution there was a transient decrease in the firing rate (Fig. 3B). Hypotonicity induces a transient increase in twitch and this was caused by the $\mathrm{Ca}^{2+}$ released from the sarcoplasmic reticulum by the low ionic strength solution (OHBA, 1984). In typical nodal cells of the rabbit, it was shown that sarcomplasmic reticulums and subsarcolemmal vesicles share some volume fractions in the cell although those are small (MASsON-Pevet et al., 1982). Thus the intracellular $\mathrm{Ca}^{2+}$ may, directly or through a $\mathrm{K}^{+}$conductance change, affect the rate of rhythmic firing in the guinea-pig S-A node.

\section{REFERENCES}

Akiyama, T. and Fozzard, H. A. (1975) Influences of potassium ions and osmolarity on the resting membrane potential of rabbit ventricular papillary muscle with estimation of the activity and activity coefficient of internal potassium. Circ. Res., 37: 621-629.

Anderson, R. H. (1972) The disposition, morphology and innervation of cardiac specialized tissue in the guinea-pig. J. Anat., 111: 453-468.

AtKins, J. M., Wildenthal, K., and HoRwitz, L. D. (1973) Cardiovascular responses to hyperosmotic mannitol in anesthetized and conscious dogs. Am. J. Physiol., 225: 132137.

BAILEY, J. C. (1981) Electrophysiological effects of hypertonic sucrose solutions on canine cardiac Purkinje fibers. Circ. Res., 49: 1112-1118.

DifrancesCo, D. (1981) A new interpretation of the pace-maker current in calf Purkinje fibres. J. Physiol. (Lond.), 314: 359-376.

Difrancesco, D. (1982) Block and activation of the pace-maker channel in calf Purkinje fibres: Effects of potassium, caesium and rubidium. J. Physiol. (Lond.), 329: 485-507.

Ehara, T. and Hasegawa, J. (1983) Effects of hypertonic solution on action potential and input resistance in the guinea-pig ventricular muscle. Jpn. J. Physiol., 33: 151-167.

EISNER, D. A. and LEDERER, W. J. (1980) Characterization of the electrogenic sodium pump in cardiac Purkinje fibres. J. Physiol. (Lond.), 303: 441-474.

FozzARD, H. A. and LEE, C. O. (1976) Influence of changes in external potassium and chloride ions on membrane potential and intracellular potassium ion activity in rabbit ventricular muscle. J. Physiol. (Lond.), 256: 663-689. 
Giles, W. R. and van Ginneken, A. C. G. (1985) A transient outward current in isolated cells from the crista terminalis of rabbit heart. J. Physiol. (Lond.), 368: 243-264.

Goto, K., Takahashi, T., Miyamae, S., and Sudo, S. (1982) Effects of Rb and Cs on the electrogenic Na-pump in rabbit sinoatrial node cells. Jpn. J. Physiol., 32: 843-854.

Hermsmeyer, K., Rulon, R., and SPERELAKIS, N. (1972) Loss of the plateau of the cardiac action potential in hypertonic solutions. J. Gen. Physiol., 59: 779-793.

IrISAWA, H. and Noma, A. (1982) Pacemaker mechanisms of rabbit sinoatrial node cells. In: Cardiac Rate and Rhythm, ed. by Bouman, L. N. and Jongsma, H. J., Martinus Nijhoff Publ., Hague, pp. 35-51.

KenYon, J. L. and GibBons, W. R. (1979a) Influence of chloride, potassium, and tetraethylammonium on the early outward current of sheep cardiac Purkinje fibers. $J$. Gen. Physiol., 73: 117-138.

KenYon, J. L. and GibBons, W. R. (1979b) 4-aminopyridine and the early outward current of sheep cardiac Purkinje fibers. J. Gen. Physiol., 73: 139-157.

Kurachi, Y., Noma, A., and IrISAWA, H. (1981) Electrogenic sodium pump in rabbit atrioventricular node cell. Pflügers Arch., 391: 261-266.

Lado, M. G., Sheu, S.-S., and Fozzard, H. A. (1984) Effects of tonicity on tension and intracellular sodium and calcium activities in sheep heart. Circ. Res., 54: 576-585.

Masson-Pevet, M., Bleeker, W. K., Besselsen, E., MackaAy, A. J. C., Jongsma, H. J., and Bouman, L. N. (1982) On the ultrastructural identification of pacemaker cell types within the sinus node. In: Cardiac Rate and Rhythm, ed. by Bouman, L. N. and Jongsma, H. J., Martinus Nijhoff Publ., Hague, pp. 19-34.

MAYLIE, J. and MoRAD, M. (1984) Ionic currents responsible for the generation of pacemaker current in the rabbit sino-atrial node. J. Physiol. (Lond.), 355: 215-235.

Maylie, J., Morad, M., and Weiss, J. (1981) A study of pace-maker potential in rabbit sino-atrial node: Measurement of potassium activity under voltage-clamp conditions. J. Physiol. (Lond.), 311: 161-178.

NoBLE, D. (1984) The surprising heart: A review of recent progress in cardiac electrophysiology. J. Physiol. (Lond.), 353: 1-50.

Noma, A., MoRAD, M., and IrISAWA, H. (1983) Does the "Pacemaker current" generate the diastolic depolarization in the rabbit SA node cells? Pflügers Arch., 397: 190-194.

Noma, A., NaKayama, T., Kurachi, Y., and Irisawa, H. (1984) Resting K conductances in pacemaker and non-pacemaker heart cells of the rabbit. Jpn. J. Physiol., 34: 245254.

OнвA, M. (1984) A role of ionic strength on the inotropic effects of osmolarity change in frog atrium. Jpn. J. Physiol., 34: 1105-1115.

Opthof, T., Jonge, B., Mackaay, A. J. C., Bleeker, W. K., Masson-Pevet, M., Jongsma, H. J., and Bouman, L. N. (1985) Functional and morphological organization of the guinea-pig sinoatrial node compared with the rabbit sinoatrial node. J. Moll. Cell. Cardiol., 17: 549-564.

RoberTs, L. A. and Hughes, M. J. (1977) Chronotropic response of spontaneously beating rabbit atria to hyperosmotic media. Am. J. Physiol., 232: H228-H233.

VAN Bogaert, P. P. and SNYDERs, D. J. (1982) Effects of 4-aminopyridine on inward rectifying and pacemaker currents of cardiac Purkinje fibres. Pflügers Arch., 394: 230238.

VASSALLE, M. (1965) Cardiac pacemaker potentials at different extra- and intracellular K concentrations. Am. J. Physiol., 208: 770-775.

Wildenthal, K., Mierzwiak, D. S., and Mitchell, J. H. (1969) Acute effects of increased serum osmolarity on left ventricular performance. Am. J. Physiol., 216: 898-904. 